\title{
Efficiency and Effectiveness of Pre-University Education in the Optics of Human Capital Theory
}

\author{
Jani Sota, Ph.D. \\ "Aleksandër Moisiu" University, Durrës \\ jani_sota@yahoo.com
}

Doi:10.5901/mjss.2013.v4n2p71

\begin{abstract}
The concept of human development through investment in education means ensuring the proper conditions for every Albanian citizen to have equal opportunities for same choices, so that successful or unsuccessful fate of someone could not be pre-determined by the place of birth, language, gender and creed. This material will explain also other notions such as: Human capital, Social capital and Knowledge capital. Terminological definitions have determined the breadth and depth of fast research, quality of pre-university education in Albania. All achievements and failures, among others, are due to efficiency and effectiveness of the educational system. At the theory and practical level of Albanian educational system such notions are new, therefore we see fit to clarify meaning in a way that educational related matters, as an important component of Human Development Index, can be better understood on one side and on the other to be clear the cross-connection of this component with other ones of this index (expected average life years of citizens and gross national income per capita and economic welfare).
\end{abstract}

Key words: Pre-university Education, Educational System, Legislation, Capital, Knowledge.

\section{Introduction}

In this study theme, except meanings of efficacy and effectiveness in pre-university education (PE), will explain other concepts that correlate with human capital (HC), social capital (SC), knowledge capital (KD) etc. Terminological explanations have set the width and depth of the Albanian state educational policies on the efficiency and effectiveness of university education after 90 s.

Efficiency represents the ratio of financial resources, time and other resources invested in education, as well as results. To be effective in education means "to achieve maximum results with less funding, fewer resources and less time and other resources invested in pre-university education." (Bertelsmann Foundation 1996). The maximum efficiency in a PE mean that all students enrolled in the first grade, after nine years, have to perform all compulsory education with the least possible financial tools and materials, as well as the registration of all children aged 6-15 years at this level.

Effectiveness is concerned with quality measurement of results. To be effective means "to do something good, something useful." (Clark, D., Lotto, S., \& Astuto, T. 1984). The effectiveness of PE in Albania, means "the best and the benefits that had and still have students who have attended compulsory education" (Beqja, Pajtim 2003). It should be noted that it is this education that affected their physical development and health, as they have developed mental skills (critical thinking, creative skills, problem solving skills, literacy skills); it has contributed to the development and enrichment of emotive world (they are emotionally stable, what kind of feelings dominate); influencing social development (communication skills, human values and human development); those who are prepared to learn throughout life, etc.

It is important to note that, a genuine study on efficiency and effectiveness make possible that to a state's educational policy becomes clear reorientation and most successful investment development of pre-university education system. In addition, it enables a reorientation in funding resources and expectations of educational institutions, which "ensure maximum results, with higher quality and value for the same amount of money, presents the reality of contemporary educational systems" (Bowles, S., \& Gintis, H. 1976).

In developed western country, where life of high level requires a significant and valuable progress, based on sustainable human development, it provides social capital. Sustainable human development with high social capital provides stability, cohesive society and open minded children, in the center of which is human being, and then 
consolidates democracy, creates the conditions for a longer life of citizens (this means better income, better public health etc.) and better access and equal public services and equality for gender, ethnic, religious groups etc.

Social capital is a relatively new concept in the social sciences, who say that "the ability of participants to a society or group that acts collectively accomplishes common goals." ${ }^{1}$ Control and active engagement, which appears in various forms of exploitation, constitutes the most important elements of social capital. From various investigations made, they show that "Various forms of social capital are necessary for economic and political development of a country, as namely decontrol and inactivity have a high economic and political price".

Human development - HD, have meant "progressive process of adding and progress oriented to improve the overall life of citizens in society" (United Nations 2005). Behaviorism theory in psychology is based on this oriented recognition. According to behaviorists, we do not know how it goes the process of gaining knowledge on individuals, because the psychological structure of individuals is unknown, is a black box (does not know all the psychological characteristics, physiological and genetic). So therefore, to assess knowledge, "we must start from the effects of external behavior, the products they are able to do. Having observed external behavior, we can give estimates as to the efficacy, as well as effectiveness, of individuals as well as society" (Healy, Tom \& Cote, Sylvain 2001).

This method, although it has many shortcomings, is practical and used for evaluating the efficiency and effectiveness of individuals, as well as social systems, such as education. The use of this method in human life has become much simpler. Thus, for example: we do not know the structure of the handset mobile phones, but are able to use it by using some strict action and feedback in the form of signs or certain tones taken from them. It has been detrimental to the education of Albania, is harmful even today the fact that changes in education are mainly based on this approach.

In this context, HD concept, the people, their needs and desires are set in its center. As such, the development is not meant to promote more revolutionary changes, but stable and permanent changes, which can also be evolutionary, but which provide economic prosperity, stability and social cohesion, social justice and equality, the rule of law and full equality of citizens before the law.

In $\mathrm{HD}$, the role of education is very important and irreplaceable. According to economists like: Adam Smith, D. Dicardo, Helvetius, Robert Owen, Philip Cooms and many others, in the past and today, education is considered the most implosive economic category. These forward-looking opinions are verified during the twentieth centuryand confirmed by science members and prominent politicians today, who have given their genius to powerful scientific discoveries and educational development policies (Smith, L., \& Keith, P 1971).

\section{Education - Teaching - Knowledgeof Human Development}

With the development of society and, in particular, the increased pace of socio-economic changes and technological importance and role of education and learning for human society have taken an increasingly greater value. Present process of Human Development is a serious important link in the chain related aspects of Education - Teaching Knowledge.

HD theory recognizes and accepts the role of ES (Education System) in general and within it recognizes the role of $\mathrm{CAB}$ in HD. Human development means "all powers and individual characteristics that are important for economic development" (Massell 1996). Uniting the people on social networks, respect nor schemes and codes and sets ethical forms of social capital.

Putting in place - the implementation of these competencies and characteristics of the individual, the HD transforms human capital of PE. We, as seen, make a substantial difference between HD and PE, as to distinguish between the possessions of money from financial capital, because the money not put into circulation is not financial capital, since it does not generate profit.

In this context, we can talk for knowledge and knowledge capital. Possession of knowledge can not be identified with knowledge capital. Having knowledge capital is only when knowledge is put in place and when it generates new knowledge and skills. Only knowledge capital is a function of $\mathrm{HD}$, and not knowledge not implemented and not producing new knowledge and skills. "According to the OECD analysis (Blöndal, Field, Girouard, 2002), the profit generated by the investment in education can be manifested with higher incomes with greater connection to the labor market, better health and a number of other non-monetary benefits. Viewed from this aspect, investment in education is part of a general political development. What this policy makes very specific is its long-term strategic character. Conceptual errors in educational policies result in prolonged consequences, which, firstly, are seen in labor market in the form of misbalanced

${ }^{I}$ www.hamdinuhiju.blogspot.com 
equilibrium, between supply and demand for occupations that later is manifested in deadlock economic situation. (Spillane 2000).

Educational policies are not only productive within HD and PE but also in the context of social capital - SC, because through the educational process they can influence the growth of social capital, including social networks, norms and values between individuals in society (Spillane, 2000, p. 44). ${ }^{2}$

The impact of educational policies lies not only in the field of human capital but also in social capital, and Fukuyama states that, "The area where governments are more likely to generate social capital is education".

Educational policies are not only productive within HD and PE but also in the context of social capital - SC, because through the educational process they can influence the growth of social capital, including social networks, norms and values between individuals in society (Spillane, 2000, p. 45) ${ }^{21}$.

Education, unlike other goods, promotes positive effects on the outer side level of society, even though the individual has direct benefits from individual knowledge and skills, which are gained in the process of education. This justifies the intervention of public authorities to finance education by private requirements. The entire society may profit from what someone is educated on."3

Factors that have been the focus of a quick research are:

- Infrastructure of PE;

- Curricula and textbooks of PE;

- Teaching methodologists and teachers' professional development;

Also, it should be noted that the PE value is based on the Millennium Development Goals (MDGs). Thus, during the last decade of the $20^{\text {th }}$ century, it has developed a range of activities at the European level and beyond for learning problems through life. It's worth mentioning that the year 1996 has been declared "European Year of Lifelong Learning" and only at the beginning of $21^{\text {st }}$ century (in 2000) were held three important meetings of the European Council: in Lisbon (March), in Santa Maria da Feira in Portugal (June) and in Nice, France (December) (Bejtja 2002).

In October 2000, based on the conclusions of the European Year of Lifelong Learning and subsequent experience gained at European and national level, the Commissionpublished the Memorandum of Lifelong Learning. It served as the basis forwide European consultation, in which participated more than 12,000 people and culminating in a conference held in Brussels on September 10, 2001. The results of this consultation were presented to the Commission Communiqué entitled "Making the European lifelong learning a reality" (November 2001). ${ }^{4}$

Activities related directly or indirectly to learning duringlife were organized by other organizations, such as UNESCO, ${ }^{5}$ OECD, ${ }^{6}$ CEDEFOP, ${ }^{7}$ ETF,${ }^{8}$ ILO ${ }^{9}$ etc. At the conclusion of these activities there were adopted important documents, such as: Education and training: Joint Announcement of BIAC ${ }^{6}$ and TUAC $^{7}$ (January 1991), Cologne Charter: Aims and tasks of lifelong learning (Adapted from G8 industrial countries, on 18 th June 1999), Resolution and the formation of human resource development (adopted on $14^{\text {th }}$ June 2000 by ILO General Conference, at its $88^{\text {th }}$ session, etc.).

During the activities mentioned and others, attention has been paid, first on processing a clear and comprehensive concept of lifelong learning. This is conditioned by the fact that $21^{\text {st }}$ century, which has already began, is defined as the era of knowledge (knowledge) and information and communication technology, and it will be characterized of changes in all spheres of life and activity of people. As stated in the recommendations of the II International Congress on Technical and Vocational Education (TVE), which was held in April 1999 in the South Korean capital, Seoul, 21st century "will bring an economy and society radically different ... ", That will have as key features" globalization, constant technological development, information and communication revolution and the rapid and ongoing social changes resulting from them" (Beqja 2003). These changes will lead to deterioration and more rapid depreciation of knowledge, skills previously acquired and at the same time the need is so quick to replace them with the new knowledge and skills.

At these summits, it has been decided that all countries have to achieve the following goals:

\footnotetext{
${ }^{2}$ National Strategy for Pre-university Education Development 2007-2013, MES Tirana, 2007, p. 7-9.

${ }^{3}$ Ibid.

${ }^{4}$ Commisions Document Sector "Lifelong Learning: Practices and figures", Lisbon, March 2000.

${ }^{5}$ United Nations Educational, Scientific and Cultural Organization.

${ }^{6}$ Organization for Economic Cooperation and Development.

${ }^{7}$ Centre Europeenne de Developpement du Formation Professionnelle.

${ }^{8}$ European Training Foundation.

${ }^{9}$ International Labour Office.
} 
to ensure primary education for all (we have yet to achieve this goal); ensure that the child mortality rate has to be less than 35 in 1000 newborns (not yet achieved) as well as the mortality rate of children up to the age of 5 years to be less than 45 children per 1000 children; achieve the same level of education for women, as well as men (have not yet achieved); reach life expectancy greater than 70 years (we have not reached - the average life of 68 years). ${ }^{10}$

To improve the efficiency and effectiveness of the quality of pre-university education we are compelled according to the following documents: European School for adults - withoutBorders, 1993; Hamburg Declaration on Adult education (Confcintea, 1997); Dakar Frameworkforconcrete action (2000);EU Commission Memorandum on Lifelong Learning (2000); Communiqué ofEU Commission on lifelong learning. ${ }^{11}$

\section{Basic Education Infrastructure and its Impact on Human Development}

The concept of human development through investment in education means ensuring to every citizen of Albania conditions and same options for the same choice, so that the best or worst fate cannot be determined in advance according to birthplace, language spoken, gender and religion.

Since the beginning, it must be said that the essential elements of the development process and basic education curriculum is also the working environment. When it comes to the working environment in schools, first of all bear in mind a whole variety of elements, ranging from the physical environment - the object, space, school classes; school equipment - equipment inventory classes, school cabinets (informatics, biology, physics, chemistry, etc.); physical safety in schools; healthy environment - permanent medical care for students, eliminating the phenomenon of child delinquency; positive school climate (harmonious relationships among teaching staff and students, mutual respect); extracurricular activities and ample recreational spaces, etc.

From what we have said, it appears that pre-university education infrastructure (PEI) is complex and determining the quality of basic education. It is an input, which depends not only the process and procedure quality of education, but also results (efficacy) and the benefits that students, parents and society take from the result (effectiveness of a quality education). PEI affects enrollment, students negotiability, the degree of student's training for economic activities, lifelong learning, etc. So the fair can be said that, PEI creates the conditions for successful learning reflects in human development, sometimes directly, sometimes indirectly. These implications, whether direct, indirect, whether will be mentioned in this part of the article.

The process of reforms in pre-university education in Albania in its breadth of coverage has necessarily included working environment in schools, as a very important component that influences the improvement of quality in education and human development. Due to the complexity and quite hard situation in which the general physical infra-structure was in Albania - almost totally destroyed by the war at the start of the reform process, the focus of its commitment and institutional activity of governmental and civil social community focused on rebuilding and repairing school objects. Besides the Ministry of Education and Science (MES), there are different governmental and non-governmental organizations that have invaluable contribution in the improvement of school infrastructure in Kosovo, where we can mention UNICEF, since that may be mentioned UNICEF, repaired and constructed 60 schools. Thus, in the period 1991 2001 in Albania are built and restructured over 1,000 school buildings that were hit by the war. ${ }^{12}$

The continued work in improving the infrastructure indicates growing awareness on educational institutions regarding the creation of a qualitative work environment. But almost total concentration, especially of MES, for new construction, on the one hand, according to the Head of Investment Directorate at MES, has led to given weight to the maintenance of existing facilities, and, on the other hand, there was no interest and the largest investment in the psychosocial aspects of the work environment in schools.

Investments in creating a psycho-social environment more convenient and attractive for learning are today one of the priorities of educational institutions in the country. This certainly has to do with the fact that dominant concepts of educational institutions in Kosovo, for what is defined as the quality of the working environment - especially in terms of the psychosocial environment in schools, are not clearly defined and developed to the extent that would allow the

\footnotetext{
${ }^{10}$ Lifelong learning and all its width. National Education Agency, Stokholm, January 2000, p. 15-16.

${ }^{11}$ International fondamental documents for education and learning (further: Fondamental dokuments ... ), Institutite for International Cooperation of German Society of Public Schools (IIZ/DVV), PRASH-K\&B: Tirana, 2002.

${ }^{12}$ Report of the Ministry of Education for the 1994-1995 school year.
} 
existence of a vision and contemporary approach to create better conditions in schools, and, in turn, consequently, raise the quality of education.

On the basis of the current legal provisions, regarding Kosovo, the local government is charged with greater powers in terms of care for the working environment in schools (Maloku 2012).From past practice in education developments, municipalities have shown little interest due to the most radical aspect in terms of improving school conditions; this is because, as some directors of Education Departments in local government bodies would explain, education is not always priority for municipal assemblies in Kosovo.

Awareness of educational institutions (MES, CED, and RED), donor community, civil society and schools to ensure quality working environment for pre-university education schools in Albania continues to grow and develop as a process. The decision to reform the country's educational institutions PEs', restructure according to module $5+4+3$, which in practice started in 2007 with the application of the ninth grade, has brought great challenges in Albanian education and not easy affordable.

In this context, one of the most challenging issues, even today, is the lack of adequate learning space. Causes of lack of space, in addition to those which are based on a lack of investment over the years and the ravages of war, normally derived from the restructuring of the education system. Reforms, enforcement of new module were launched in the first pre-school infrastructure for the old module, Primary Eight. This has hindered the learning process in many schools of the country, pushing schools to work with two shifts, such as the gymnasium "Qemal Stafa" in the city of Tirana, which has 2,500 students, organizes educational comprehensive school in two shifts, while legal provisions stipulate the first classes be organized in two shifts.

The opinion of the majority of directors and PE teachers is that lack of adequate learning space causes major obstacles to the progress of learning, because this lack imposes overload of classes with students - many are cases where a class has about 45 students. This reality is omnipresent in our nation's schools, especially in the most prestigious high schools, the largest cities in the country, being in flagrant contradiction with the regulations in force for the space-student report, which provides 2 square meters for each student. ${ }^{13}$ There are very clear indications that the process of education reforms are yet to create the conditions to meet the needs and requirements in terms of environmental quality in schools.

If we make a comparison between the situation that currently prevails in schools, in terms of quality of the work environment and the aims and objectives arising from PE reform process in Albania, there is an inconsistency that really highlights the lack of commitment necessary to institutional education with MES ahead of organization, to due attention to the improvement of learning conditions. This confirms even an MES official responsible for basic education, according to which, despite the huge commitment of this ministry to create enough space and attractive environments to work in schools, the situation is still far from the standards that reforms achieved prescribe.

On the other hand, UNICEF is constantly engaged in projects aimed at improving the working environment in schools, the quality of the work environment in schools is not given sufficient importance, the fact that in most cases the educational policy-making initiatives by MES has always come from above, often not being able to take into account the real needs of schools in different regions.

Law on Primary and Secondary Education in Albania, adopted by the Parliament in 2002, has established the general framework of functions of primary and secondary education in the country, including the issue of quality work environment. Although not to the extent necessary and in a comprehensive manner, the law provides in some parts of its regulation various aspects of the work environment in schools. However, we think that this law is not sufficient, and in this way its working draws to more administrative orders, that there are no legal infrastructure problems.

Funds for providing quality work environment in schools undoubtedly constitute the "Achilles heel" in the whole process of the operation of the education system in Albania and implementation of legislation in education. Under education law, funds are provided under the general provisions of law applicable to the financing of public services in Kosovo.

More specifically, the Ministry of Education allocate funds to municipalities and communes in order for them to perform their functions in the field of PE, then the local governments or municipalities set funds for educational institutions within its territory, which these plan and administer themselves. This is the general way how the process works and use of securing necessary finances for pre-university education, where a certain part of these funds are designed for the working environment. According to MES officials, the institution allocates annually 7-8 million $€$ for construction issues and maintenance of school facilities, along with other tools provided by municipalities and foreign investors, who do not nearly meet current requirements and needs in basic education.

\footnotetext{
${ }^{13}$ Democratic culture, a challenge for schools, UNESCO, EduALBA - Tirana, 1999, p. 29.
} 
Namely the issue of management and distribution of funds for the work environment in schools appears to have caused quite a lot of difficulty even for school principals and, in many cases, be a hindrance to improve working conditions in schools. District and school education principals have many complaints about what they call centralization by MES in Albania. This has to do mainly with the fact that schools do not manage funds provided for expenditure by them, but they are managed by directories - Regional Education Directorate (RED).

The current legal infrastructure in the field of education has not sufficiently involved psycho-social aspects of the work environment in the school, which is reflected in the absence of facilities in many schools, making them not having the attributes of one of the agents - the most important of socialism. But, with regard to those matters that are prescribed by law, can not be said that things stay good, especially because of lack of accordance between the real situation and legal provisions. Many teachers and school principals complain that the law does not take into account the real situation in Kosovo, and, as such, many of its provisions are unusable.

What is mainly spoken here is failure of MES to provide free textbooks for schoolchildren of first level, which is required by law - section 3.2 (b), or even on the issue of providing transportation for students in PE - Article 22.1, which is local government competency.

In fact, the problem is the fact that the question of the existence of separate mechanisms for the working environment is not properly regulated by law, and thus is not provided as fund raising, especially for the working environment. In this context, as the schools are better; budgetary constraints relate to those municipalities that lack technical staff (security, cleaners, administrative staff) to be highly expressed, never mind then to others, such as pedagogue, psychologist, doctor, etc.

Access to educational institutions in the country, in terms of their organizational structure and mechanisms that operate within them, is a comprehensive approach - local and central administration in educational institutions is not structured on the basis of specifications and needs of various individual educational components. This also confirms the assertion of an MES officer, responsible for primary education, with all its administration the ministry works towards the creation of favorable environment for work.

What greatly hinders mutual cooperation is the lack of job competencies of schools and lack of technical school staff (maintenance). Another obstacle influencing on the lack of sufficient cooperation between schools and local and central institutions of education, in terms of working environment, is the issue of excessive procedural bureaucracy, which greatly hinders the effectiveness of schools. More specifically, it comes to procurement procedures, which brings more problems, when it comes to intervene, even for very small technical things, such as a change of any door or broken glass.

\section{Curricula and Textbooks,their Impact on the Human Development}

Curricular programming as a new working method of learning process, for the first time, found application in year 1960, initially in the U.S. and then, in other western countries. Unlike traditional activities at school, which were guided by the general teaching plan whether the program was thematic descending or analytical with content of a unified curriculum summary, a system of knowledge practices and planning of teaching program functioned in breadth and depth. It dealt, guided and taught during the knowledge acquisition by the student.

The right to education is a fundamental human right, which meets specific weight for the physical, human and social capital development not only of a country but also of our planet as a whole. For this reason, the right to education is a right guaranteed in the Universal Declaration of Human Rights (UDHR), the Convention on the Rights of the Child of United Nations. Universal right to participate in basic education is to put on top of the list millennium goals set by the United Nations. However, participation in education is still low in many countries of the world.

Research shows that in 2000, more than 113 million children did not attend primary education, 880 million adults are illiterate; gender discrimination continues to survive in many educational systems and the human values and skills is far from the aspirations and needs of individuals and societies. ${ }^{14}$ These data are the basis for a greater commitment to universal participation in basic education that has taken on global measures after the World Education Forum meeting in April 2000 in Dakar, Senegal. ${ }^{15}$ Education is considered as one of the basic areas of development, peace and stability between countries and one of the main mechanisms for effective participation in the societies and economies of the 21 st century, under the auspices of the accelerated process of globalization. ${ }^{16}$ But efforts to actively participate do not

\footnotetext{
${ }^{14}$ Fondamental documents ... , p. 55.

${ }^{15}$ Dakar Framework for Action, Education for All, Dakar Senegal, 26-28 April 2000, p. 2.

${ }^{16}$ Ibid, p. 4.
} 
necessarily guarantee quality education, therefore the continuous improvement of quality to improve the quality of education, stability and progress of quality education, would be an inevitable part of these efforts.

The human notion of education quality is a broad concept, comprehensive and complex, which not only focuses on policy and planning at the national level, but also pays particular attention to the implementation of school policies and classroom learning environments, etc. of Human Development and social capital, should an efficient planning and managing and implementation, monitoring and evaluation of tracking real transparency and accountability of large input conditions in which the PE, the processes to develop basic education, the results arises from the process of education as well as impacts of results in physical development, personal traits of students that are necessary for economic development, as well as recognition, respect and adherence to the values that are beneficial to citizens social welfare for democracy, social justice and the rule of law. Only in this way the educational system in Albania performs a functional human development.

But for that to happen in this process, there should be a broad involvement of actors and partnership at all levels of society. Above all, high-quality, policy, planning and school practices should aim to address the interests, needs and success of students as a final goal. Interests, the needs of students, the needs of society for technical developments, technological, scientific, social and physical development of students, to increase human development index should be addressed in the curricula and textbooks, which illustratively are nothing than "food" for human development and social capitals for the Albanian society.

Therefore improvements must be made in curricula and textbooks for: "improving the quality of education, which certainly requires the adaptation of the curriculum content, (textbooks-JS) and processes aimed at putting the student at the center, to recognize and apply diversity of needs, interests and stages cognitive development, social and emotional development of students and development of knowledge, skills and attitudes that enable an individual to learn independently, learning and solving problems related to school."

These changes are closely related to human development concepts, since the curriculum is an important contribution and without avoiding human resource development. The very concept of development means creating an environment where one can develop its full potential and have a productive, creative life coinciding to needs and interests. But since the concept of development sees people not as a means, but as ends in themselves, human development is the process of expanding opportunities and choices. To achieve this, it should have access to knowledge and information, access to resource materials for a decent standard of living and free participation in community life for collective matters (Shera 2001).

Research shows that investment in PE in general and curriculum specifically, influence the impact on human development, since the content of education, respectively curriculum guides or learning process toward defined goals on some individual abilities and skills can be brought into life in practice.

Reformations of educational content in Albania from 2002-2007 aimed to change the contents of the curricula and teaching methods from the perspective of human development and the need for lifelong education. Main goal is to enable children and young people to contribute effectively in preparing the new generation for successful and active participation in society. But to achieve this goal, there is a need for comprehensive and qualitative reform of curricula and textbooks, and an effective, efficient and sustainable development.

The term curriculum is a relatively new term in the Albanian education. In Albania, it has been used since 2000 . Terminology changes the curriculum in itself, meaning that there has been a tendency to change the approach to content and implementation of content in the Kosovar education system.

Curricula changes, however, are closely related to the conception of the curriculum, despite what curriculum is and what purpose does it have remains a controversial issue. From a traditional angle, this concept is narrow and focuses mainly on the content of a subject and the transmission of this content to students, initiating a process closer to understanding, mainly at the level of object recognition, memorization and repetition of information and knowledge. As a result of such an approach, the knowledge of the teacher is "Transferred" to the student and "not detected" along with limited teaching, learning and assessment in a supposed "correct answer".

Paulo Freire, Brazilian education expert, familiar with the metaphor "banking system" of learning, has criticized by claiming that such access is limited to the process of receiving knowledge, organizing, sorting and disposal of knowledge at the end. According to him, students are the ones who lose all creativity, the ability to transform and knowledge required in such a disoriented system of teaching and learning (Freire 2001). Traditional education and the traditional concept of challenged and constantly changing curriculum is not just as a concept, but also as a practice through new liberal educational trends and democratic curriculum development. With new trends, when curriculum has a more comprehensive and broader concept, exceeds the highest concentration in the content and gives greater focus in the 
process of promoting student learning. Greatest concentration in learning according to Dewey, American education expert, defines curriculum as a field of which deals with the experiences of students or even all the experiences that the child receives under instruction of teachers. Or, the curriculum is conceived as an environment where children carry themselves an active part in learning (Hunkins \& Ornstein 2003)

Emphasis on the student-centered teaching process and learning means objectives that help transition from memorizing the facts, events, names, dates, and formulas in the curriculum to challenge thinking, analyzing the ideas and personal experiences to him / her. Such goals have redesigned it as stresses Oakes and Lipton, "real model of training students in solving problems to create people who know how to identify and resolve problems (Oakes \& Lipton, 2003). So changes incline towards connecting refrained curriculum and implementation of content experiences of human beings, as well as education is seen related to the work experience and community life as claims Dewey, (2003) "schools is a miniature of a democratic society where children live, not a place where only learn lesson units".

These new concept are also the basis of changes in education in Albania. Latest trends in the development of advanced curricula in learning with constructive teaching with student at the center will develop abilities and skills like critical thinking, solving problems, creativity, curiosity, high intellectual abilities, which have been goals for curricular changes in Albania. As stated in the curriculum framework, curriculum-based document in Albania, "curriculum is assessed as a coherent articulation of goals and objectives, contents, methods of teaching and learning and as a basis for evaluation ... and predicts how students should prepare" (IKS 2007)

Provisions of curriculum address important issues dealing with what issues need to know and what they should be able as students, which values should be cultivated, how students will live together and how to support the development of their full potential so that they can actively contribute to the welfare of society and personal welfare. Also, in this framework, a whole chapter specifies in detail the principles and structures of curriculum subjects.

One of the documents related to school activities, as well as educational managing institutions is the "Normative Provisions for Public Schools", which came into effect in the academic year $1996-1997^{17}$, in support of the Law $\mathrm{nr} .7952$, dated 21.06.1995 ${ }^{18}$. In its article 25 it quotes on special attention and knowledge assessment of student conduct: "Assessment of the level of knowledge, abilities and practical skills of students is an important issue and parcel of all teaching and educational work in schools. Evaluation is done with the note or phrase. Assessment is made by the teacher" $" 19$.

At the end of the first decade, fueled by European educational policies MES made the task on establishing the National Education Assessment Centre (Axhemi 2001). The establishment of the center is estimated at the National Education Strategy 2004-2015, as one of the two important institutional reforms of the second decade in the Albanian education transformations. Its establishment will mark the beginning of the institutionalization of evaluative institutions in Albania ${ }^{20}$

\section{Conclusions}

In the above paragraphs we expressed the importance of human capital formation to increase the efficiency and effectiveness of pre-university education. The studies clearly see that there is a close relationship between human capital formation for the $21^{\text {st }}$ century competencies and quality growth in PE.

One of the greatest benefits of continuing education is that it can improve one's skills in a current job or help gain new skills in preparation for a career change. Necessary skills in the areas of work may change over time, so people must continue learning and be prepared for possible changes. Continuing education is also very important for those who plan for a future career or appropriate one according to their abilities in the labor market.

\section{Bibliography}

Axhemi. Sokol, Speech held at the National Seminar: "Monitoring and Evaluating Albanian Education", Tirana, December 6, 2001

Bejtja, Pajtim, Toward the establishment of a European space for lifelong learning, Pedagogical Review, nr. 4, Tirana, 2002

\footnotetext{
${ }^{17}$ Ministry of Education and Science (1996), Normatives, Tirana.

${ }^{18}$ Law Nr. 7952, date 21. 6. 1995, "On pre-university education in the Republic of Albania" (adjourned)", Article 25, Parliament of Albania, Tirana, 1995.

${ }^{19}$ Law Nr. 9741, date 21. 5. 2007, "On Higher Education in the Republic of Albania (adjourned)", Parliament of Albania, Tirana, 2007.
} 
Beqja, Pajtim., (2003). Learning in todays society (further: Learning in ... ), Tirana,

Beqja, Pajtim., (2003). Learning in todays society (further: Learning in ... ), Tirana

Bertelsmann Foundation (1996). Innovative school systems in an international comparison,

Gutersloh, German Bowles, S., \& Gintis, H. (1976). Schoolling in capitalist America, New York: Basc Books

Centre Europeenne de Developpement du Formation Professionnelle.

Clark, D., Lotto, S., \& Astuto, t. (1984). Effective schools and school improvement: A Comparative analysis of to lines of inquriy, Educational Administration Quarterly, 20 (3)

Commisions Document Sector "Lifelong Learning: Practices and figures", Lisbon, March 2000.

Dakar Framework for Action, Education for All, Dakar Senegal, 26-28 April 2000, p. 2.

Democratic culture, a challenge for schools, UNESCO, EduALBA - Tirana, 1999

Dewey, John. 2003. School and society, "Plejad": Tirana

European Training Foundation.

Freire, Paulo (2001), The Pedagogy of the Oppressed.

Healy, Tom \& Cote, Sylvain., (2001). The well-being of nationas: ther role of human and social capital, OECD 2001

Hunkins dhe Ornstein (2003), Curricula, basis, principles and problems

IKS, Curricula on school basis (Module curricula), Tirana, 2007

International fondamental documents for education and learning (further: Fondamental dokuments ... ), Institutite for International Cooperation of German Society of Public Schools (IIZ/DVV), PRASH-K\&B: Tirana, 2002

International Labour Office.

Law Nr. 7952, date 21. 6. 1995, "On pre-university education in the Republic of Albania" (adjourned)", Article 25, Parliament of Albania, Tirana, 1995

Law Nr. 9741, date 21. 5. 2007, "On Higher Education in the Republic of Albania (adjourned)", Parliament of Albania, Tirana, 2007

Lifelong learning and all its width. National Education Agency, Stokholm, January 2000

Maloku, Fadil. "Globalization, a myth or process?", Kosova Press, Pristina, April 29, 2012.

Massell, D., (1996). State strategies for building capacity in education, Chicago: University of Chicago Press.

Ministry of Education and Science(1996), Normatives, Tirana

National Strategy for Pre-university Education Development 2007-2013, MES Tirana, 2007

Oakes and Lipton, (2003)., Teaching to Change the World

Organization for Economic Cooperation and Development.

Report of the Ministry of Education for the 1994-1995 school year.

School is ours, OFSA, Tirana,2004

Smith, L., \& Keith, p., (1971). Anatomy of educational innovation: An organizational analysis of an elementary school, New York: Wiley

Spillane, J., (2000). Cognition and policy implementation: District policymakers and the reform of mathematics education, Cognition and Instruction, 18 (2)

Shera, Përparim., Evaluating learning in pre-university education, Pedagogical Review, nr. 4, Tirana, 2001

United Nations Educational, Scientific and Cultural Organization.

United Nations, The Millennium Development Goals Report 2005, New York, 2005

www.hamdinuhiju.blogspot.com 
